Full-text Available Online at $\underline{\text { www.bioline.org.br/ja }}$
J. Appl. Sci. Environ. Mgt. September, 2006

Vol. 10 (3) 163- 166

\title{
The Effect of Two African Mineral Dyes on the Activity of Alkaline Phosphatase in the Skin and Serum of Albino Rats
}

\author{
${ }^{1}$ ADEBAYO, GB, ${ }^{2}$ SUNMONU,T O ${ }^{3}$ ADEKOLA, FA; ${ }^{3}$ OLATUNJI ,GA
}

\author{
${ }^{1}$ Department of Chemistry, Kwara State Polytechnic, Ilorin, P. M. B 1375, , Ilorin, Nigeria. \\ ${ }^{2}$ Department of Biochemistry, University of Ilorin, P. M. B. 1515, , Ilorin, Nigeria. \\ ${ }^{3}$ Department of Chemistry, university of Ilorin, P. M. B. 1515, , Ilorin Nigeria
}

\begin{abstract}
The effect of two African mineral dyes Yombo tumtum (YT) and Yombo fita (YF) on the activity of alkaline phosphatase (ALP) in the skin and serum of albino rats was investigated. The chemical analyses of the dyes were first carried out using solubility test, $\mathrm{pH}$ determination and X-ray fluorescence (XRF) elemental analysis. Six different concentrations $(0.05,0.15,0.25,0.5,0.75$ and $1.00 \%)$ of each dye were prepared using hydrogen peroxide as solvent. A total of 70 albino rats (Rattus norvegicus) were used for the study. The rats were grouped into 14 of 5 rats and were maintained on commercial feed for a period of 30 days, during which the experiment lasted. Group I served as the first control and the animals had distilled water applied on their heads. Group 2 which served as the second control contained rats on whose heads were applied the dissolving solvent i.e. hydrogen peroxide. Rats in group 3 to 8 had the various concentrations of YT (black) dye applied on their heads, while those in groups 9 to 14 had the various prepared concentrations of YF (white) dye applied on their heads. At the end of the experiment, blood samples were collected and portion of the head skin where the dyes were applied was cut. The activity of ALP was thereafter determined in the serum and skin of the experimental animals. The results revealed a significant decrease $(p<0.05)$ in the activity of ALP as the concentration of the dye increased in both the serum and skin@JASEM.
\end{abstract}

The use of hair dye is fast gaining popularity especially among ladies and old men. Young ladies engage in the use of dyes mainly for fashion while old men use dyes to mask their grey hair. Dyes are basically of two types namely natural dyes and synthetic dyes. Natural dyes include plant dyes, animals and mineral dyes. Plant dyes can be obtained from roots, flowers, leaves, fruits and bark of plants such as wood and indigo. Some animal sources of dyes include insects such as Cochineal, found on Cacti in Mexico, Lac found in India and Iran and kermes, found on oak tree near the Mediterranean. Mineral dyes come from ocher (yellow, brown, red); limestone or lime (white), manganese (black), cinnabar and lead oxide (red) azurite and lapis lazuli (blue), and Malachite (green)( Wayne, 1994). The use of synthetic dyes became paramount in the midnineteenth century when the demand for hand-made rugs increased in the West. The need for easy to use and less expensive dyes with wider range of colours led to the development of synthetic dyes in Europe especially in Germany. The first synthetic dye, Fuchsine (magenta aniline) was developed in the 1850 s. Other synthetic aniline dyes such as chrome dyes were later developed.

Hair dyes can be either temporary or permanent dyes with varying chemicals which may be poisonous to the users. Temporary dyes contain silver, mercury, lead, arsenic, bismuth, paragallol and denatured alcohol while permanent dyes contain naphthylamine, phenylenediamines, toluene-diamines and other aromatic compounds. Most people dye their hair without considering the side effects of the chemical constituents of the dye. The decision to change hair colour has recently become more complicated due to some recent studies which linked hair colouring with an increase risk of contacting certain cancers (Patlak, 1993). Several other studies on dyes have been carried out by various researchers which implicated dyes as carcinogens (Coldiz, 1994, Chase, 1998, Oncolink, 1999). It has also been reported that hair dyes may be hazardous to children's health due to the presence of lead in the form of lead acetate, as exposure to such leadcontaining hair dyes can cause neurological problems (Marcus, 1997). Other symptoms such as local skin irritation can be associated with toxic substances in the hair dyes (Coldiz, 1994). Alkaline phosphatase is an enzyme, or more precisely a family of related enzymes, produced in the bile ducts, intestine, kidney, placenta and bone. It is mostly found in an alkaline state with a $\mathrm{pH}$ of 9 . It is used extensively as a tumor maker and also present in bone injury, pregnancy, or skeletal growth. An elevation in the level of serum alkaline phosphatase suggests disease of the bile ducts. Serum alkaline phosphatase activity can be markedly elevated in bile duct obstruction or in bile duct diseases such as primary biliary, cirrhosis or primary sclerosing cholangitis. ALP is also a "marker enzyme" for the plasma membrane and endoplasmic reticulum (Akanji, et al, 1993). 
Therefore damage to the membrane especially in the skin may adversely affect the activity of ALP

The present study is therefore aimed at exploiting the activity of alkaline phosphatase (ALP) which is a membrane-bound enzyme as a possible means of understanding the toxicological effect and the mechanism of action of two African mineral dyes YT (black) and YF (white) which are commonly used in Nigeria for dyeing hair.

\section{MATERIALS AND METHODS}

Source of the dye: Two samples of rock-like mineral dyes were obtained from Emir's Market in Ilorin, Nigeria. The Local names of the dyes are YomboTumtum (YT) for black and Yombo-fita (YF) for white. The original source of the samples was traced to the Southern part of Ghana.

Solubility test: The solubility of each dye sample was investigated in fourteen different solvents. The solvents include deionized water, hydrogen perioxide, Acetone, benzaldehyde, acetaldehyde, ethanol, petroleum ether, concentrated $\mathrm{HNO}_{3}$, concentrated $\mathrm{HCl}$, methanol, diethyl ether, ethyl acetate, acetic acid and aniline. The test was carried out by adding $10 \mathrm{mg}$ of the well ground $(<80 \mu \mathrm{m})$ to $5 \mathrm{~cm}^{3}$ of each of the above solvents in a test tube at room temperatures. Where the dye was not soluble in the cold, a gentle heat was applied placing the test tube inside a heated water-bath (Adetuyi et. al., 2003).

Elemental analysis of the dye: Each sample was crushed and ground in a Tungsten Carbide Spex Mill followed by other procedures specific for the method of analysis (Potts, 1993). Each sample was then analyzed for trace elements using Energy Dispersive $\mathrm{X}$-ray Fluorescence (ED-XRF) Spectrophotometer. The EDXRF facility consists of two interchangeable $\left({ }^{55} \mathrm{Fe}\right.$ and $\left.{ }^{109} \mathrm{Cd}\right)$. Annular source, a Canberra model SL 12170 silicon solid state detector and the associated pulse processing electronic which are coupled to ADC-Card. The facility runs on PC with Maestro software for spectra acquisition. Sensitivity calibration was done using thick pure metal foils ( $\mathrm{Ti}$, $\mathrm{Fe}, \mathrm{Co}, \mathrm{Ni}, \mathrm{Cu}, \mathrm{Zn}, \mathrm{Zr}, \mathrm{Nb}, \mathrm{Mo}, \mathrm{Sn}, \mathrm{Ta}, \mathrm{Pb}$ ) and stable analytical grade chemical compound $\mathrm{K}_{2} \mathrm{CO}_{3}$, $\mathrm{CaCO}_{3}, \mathrm{Ce}_{2} \mathrm{O}_{3}, \mathrm{WO}_{3}, \mathrm{ThO}_{2}$ and $\mathrm{U}_{3} \mathrm{O}_{8}$. Quantification of the concentrations of detectable elements was done using a modified version of emission transmission method (Potts et. al., 1984).

Preparation of different concentrations of the dyes: Six different concentrations of each dye (YT and YF) were prepared $(0.05,0.15,0.25,0.50,0.75$ and
$1.00 \% \mathrm{w} / \mathrm{v}$ ) using Hydrogen peroxide as the dissolving solvent. For example, $0.05 \%$ concentration was prepared by dissolving $0.05 \mathrm{~g}$ of the dye in $100 \mathrm{~cm}^{3}$ of hydrogen peroxide in $100 \mathrm{~cm}^{3}$ volumetric flask.

Experimental Animals: A total of 70 albino rats (Rattus norvegicus) with an average weight of $26.8 \mathrm{~g}$ were used for the study. The rats were grouped into 14 of 5 rats each as follows.

Group 1:Rats on whose heads were applied $2 \mathrm{~cm}^{3}$ distilled water (Control 1)

Group 2:Rats on whose head were applied $2 \mathrm{~cm}^{3}$ of dissolving solvent $\left(\mathrm{H}_{2} \mathrm{O}_{2}\right)$

Group 3:Rats on whose heads were applied $2 \mathrm{~cm}^{3}$ of $0.05 \%$ conc. YT dye

Group 4:Rats on whose heads were applied $2 \mathrm{~cm}^{3}$ of $0.15 \%$ conc. YT dye

Group 5:Rats on whose heads were applied $2 \mathrm{~cm}^{3}$ of $0.25 \%$ conc. YT dye

Group 6:Rats on whose heads were applied $2 \mathrm{~cm}^{3}$ of $0.50 \%$ conc. YT dye

Group 7:Rats on whose heads were applied $2 \mathrm{~cm}^{3}$ of $0.75 \%$ conc. YT dye

Group 8:Rats on whose heads were applied $2 \mathrm{~cm}^{3}$ of $1.00 \%$ conc. YT dye

Group 9:Rats on whose heads were applied $2 \mathrm{~cm}^{3}$ of $0.05 \%$ conc. YF dye

Group 10: Rats on whose heads were applied $2 \mathrm{~cm}^{3}$ of $0.15 \%$ conc. YF dye

Group 11: Rats on whose heads were applied $2 \mathrm{~cm}^{3}$ of $0.25 \%$ conc. YF dye

Group 12: Rats on whose heads were applied $2 \mathrm{~cm}^{3}$ of $0.50 \%$ conc. YF dye

Group 13: Rats on whose heads were applied $2 \mathrm{~cm}^{3}$ of $0.75 \%$ conc. YF dye

Group 14: Rats on whose heads were applied $2 \mathrm{~cm}^{3}$ of $1.00 \%$ conc. YF dye

The different concentrations were applied every three days and the experiment lasted for 30days. The dye was applied every three days to depict continuous and prolong usage of the dye. All the rats were housed in separate metabolic cages and fed ad libitum with commercial rat chow and water. At the expiration of 30days blood samples were collected and portion of the head skin where the dyes were applied was cut.

Assay for Alkaline Phosphatase Activity: The activity of ALP was assayed in the skin and serum of the rats using the modified method of Wright and Plummer (1974). Two test tubes labelled blank and test were placed in the test tube rack. $2.2 \mathrm{ml}$ of $0.1 \mathrm{M}$ carbonate buffer was pipetted into the test tubes. $0.1 \mathrm{ml}$ of $0.1 \mathrm{M}$ $\mathrm{MgSO}_{4} \cdot 7 \mathrm{H}_{2} \mathrm{O}$ was added into the test tube. $0.2 \mathrm{ml}$ 
distilled water and homogenate was added into the blank and test tubes respectively. The mixture was shaken and incubated in water bath at $37^{\circ} \mathrm{C}$ for 10 minutes. $0.5 \mathrm{ml}, 19 \mathrm{Mm}$ PNPP was added into each of the test tubes and incubated in water bath at $37^{\circ} \mathrm{C}$ for another 10 minutes. Finally, $2.0 \mathrm{ml}$ of $1 \mathrm{~N} \mathrm{NaOH}$ was added into the test tubes and absorbance of test against blank was taken at $0,1,2$ and 3 minutes at $400 \mathrm{~nm}$. The absorbance readings obtained were then used to calculate the specific activity of Alkaline Phosphatase (ALP).

\section{RESULTS AND DISCUSSION}

Solubility Test: The results of the solubility test of the two samples of dye show that the two dye samples were soluble in almost all the solvents employed (except petroleum ether and concentrated $\mathrm{HCl}$ ) with the solution having different colours. Almost all colours appear to be unstable as they changed after 24 hours. The samples were found to be soluble in both polar and non-polar solvents. The solubility of samples may be attributed to the presence of both organic and inorganic components in the samples. The colour observed may be attributed to the existence of certain complexes involving some elements within the sample and organic species acting as ligands. The $\mathrm{pH}$ of the resulting aqueous solution shows that the samples were slightly alkaline. This may be due to the presence of carbonates or hydrogen carbonate of alkaline and alkaline earth metals in the samples. The solubility of the samples in both polar and non-polar solvents probably explains penetrating ability of the dyes into different surfaces.

Elemental X-ray Flourescence (XRF) Analysis: The results of XRF analysis of the two samples YT and
YF are summarized in Table 1. Twenty elements were recorded and concentrations range from major to ultra-trace levels. The major elements include Potassium (K) and Sodium (Na). Minor elements are $\mathrm{Ti}, \mathrm{V}, \mathrm{Cr}, \mathrm{Zn}, \mathrm{Mn}$, and $\mathrm{Fe}$, trace elements $\mathrm{Co}, \mathrm{Ni}, \mathrm{Cu}$, $\mathrm{As}, \mathrm{Pb}$ and $\mathrm{Zr}$ and the ultra trace elements include $\mathrm{Rb}, \mathrm{Sr}, \mathrm{Y}$ and Mo. The results of XRF reveal that these dyes may have certain degree of deleterious effect due to the presence of toxic metals such as As, $\mathrm{Pb}, \mathrm{Cr}, \mathrm{Co}$, and $\mathrm{Zn}$-in the two samples. Some of the elements detected in the dyes are trace elements which have been found to be potent carcinogens. Studies have shown that elements such as $\mathrm{Cr}, \mathrm{Pb}, \mathrm{As}$, and $\mathrm{Cu}$ are potent carcinogens (De Zwart and Sluoff, 1987). This probably account for the implication of heavy metals on the etiology of cancer.

Specific Activity of Alkaline Phosphatase (ALP): The specific activity of ALP in the skin and serum of the rats following the application of the two samples of the dye is presented in Table 2. The significant reduction $(p<0.05)$ in the specific activity of the enzyme as the concentration of the dye increases in the skin and serum may in part be due to damage to the tissues. ALP is a "marker enzyme" for the plasma membrane and endoplasmic reticulum. Therefore damage to the membrane especially in the skin may adversely affect the activity of ALP. The reduction in ALP activity could also be attributed to inhibition of the enzyme by the dye as is the case with consumption of metabisulphite (Akanji et. al., 1993), or inactivation of the enzyme molecules in situ (Umezawa and Hooper, 1982). The gradual reduction in enzyme activity as the concentration of the dye increases has clearly demonstrated that the dye has a pronounced effect on the skin and serum.

Table 1: Elemental analysis of YT and YF by XRF techniques

\begin{tabular}{|l|l|l|l|}
\hline $\mathrm{S} / \mathrm{NO}$ & $\mathrm{ELEMENT}$ & SAMPLE YT & SAMPLE YF \\
\hline 1 & $\mathrm{~K}$ & $0.43(\mathrm{p})$ & $0.43(\mathrm{p})$ \\
\hline 2 & $\mathrm{Ca}$ & $0.26(\mathrm{p})$ & $0.26(\mathrm{p})$ \\
\hline 3 & $\mathrm{Ti}$ & $0.07(\mathrm{p})$ & $0.07(\mathrm{p})$ \\
\hline 4 & $\mathrm{~V}$ & 348 & 345 \\
\hline 5 & $\mathrm{Cr}$ & 204 & 207 \\
\hline 6 & $\mathrm{Mn}$ & 151 & 175 \\
\hline 7 & $\mathrm{Fe}$ & 125 & 125 \\
\hline 8 & $\mathrm{Co}$ & 66.0 & 66.0 \\
\hline 9 & $\mathrm{Ni}$ & 42.0 & 53.0 \\
\hline 10 & $\mathrm{Cu}$ & 43.0 & 35.0 \\
\hline 11 & $\mathrm{Zn}$ & 123.0 & 26.0 \\
\hline 12 & $\mathrm{As}$ & 23.0 & 21.0 \\
\hline 13 & $\mathrm{~Pb}$ & 33.0 & 31.0 \\
\hline 14 & $\mathrm{Br}$ & 8.00 & 13.0 \\
\hline 15 & $\mathrm{Rb}$ & 7.00 & 9.00 \\
\hline 16 & $\mathrm{Sr}$ & 7.00 & 9.00 \\
\hline 17 & $\mathrm{Y}$ & 7.00 & 9.00 \\
\hline 18 & $\mathrm{Zr}$ & 11.0 & 6.00 \\
\hline 19 & $\mathrm{Nb}$ & 15.0 & 30.0 \\
\hline 20 & $\mathrm{Mo}$ & 5.00 & 5.00 \\
\hline Note: $(\mathrm{p}) \rightarrow$ Values in Percentage, others are in ppm.
\end{tabular}


Table 2: Specific activity of alkaline phosphatase in the skin and serum of rats following the application of dye

\begin{tabular}{|l|l|l|l|l|}
\hline \multirow{3}{*}{ Concentration of Dye } & \multicolumn{4}{|c|}{ Specific activity $\mu \mathrm{mol} / \mathrm{mg}$ protein/min } \\
\cline { 2 - 5 } & Skin & \multicolumn{4}{|c|}{ Serum } \\
\cline { 2 - 5 } & Yombo Tumtum (YT) & Yombo Fita (YF) & Yombo Tumtum (YT) & Yombo Fita (YF). \\
\hline Control & $8.74 \pm 0.09^{\mathrm{a}}$ & $8.14 \pm 0.08^{\mathrm{a}}$ & $8.29 \pm 0.24^{\mathrm{a}}$ & $8.02 \pm 0.02^{\mathrm{a}}$ \\
\hline Solvent & $6.90 \pm 0.10^{\mathrm{b}}$ & $6.85 \pm 0.09^{\mathrm{b}}$ & $5.46 \pm 0.00^{\mathrm{b}}$ & $5.15 \pm 0.01^{\mathrm{b}}$ \\
\hline $0.05 \%$ & $5.74 \pm 0.05^{\mathrm{c}}$ & $5.21 \pm 0.05^{\mathrm{c}}$ & $4.24 \pm 0.08^{\mathrm{c}}$ & $4.04 \pm 0.03^{\mathrm{c}}$ \\
\hline $0.15 \%$ & $4.12 \pm 0.02^{\mathrm{d}}$ & $3.91 \pm 0.02^{\mathrm{d}}$ & $3.36 \pm 0.07^{\mathrm{d}}$ & $3.01 \pm 0.00^{\mathrm{d}}$ \\
\hline $0.25 \%$ & $2.48 \pm 0.04^{\mathrm{e}}$ & $2.16 \pm 0.03^{\mathrm{e}}$ & $2.72 \pm 0.09^{\mathrm{e}}$ & $2.25 \pm 0.03^{\mathrm{e}}$ \\
\hline $0.50 \%$ & $1.80 \pm 0.00^{\mathrm{f}}$ & $1.30 \pm 0.00^{\mathrm{f}}$ & $2.11 \pm 0.02^{\mathrm{f}}$ & $1.98 \pm 0.01^{\mathrm{f}}$ \\
\hline $0.75 \%$ & $0.99 \pm 0.03^{\mathrm{g}}$ & $0.81 \pm 0.01^{\mathrm{g}}$ & $1.54 \pm 0.01^{\mathrm{g}}$ & $1.34 \pm 0.03^{\mathrm{g}}$ \\
\hline $1.00 \%$ & $0.42 \pm 0.02^{\mathrm{h}}$ & $0.31 \pm 0.02^{\mathrm{h}}$ & $0.97 \pm 0.05^{\mathrm{h}}$ & $0.63 \pm 0.01^{\mathrm{h}}$ \\
\hline
\end{tabular}

Note: $\quad$ Each value is a mean of five determinations \pm SEM; $a, b, c, \ldots$ column values with different superscripts are significantly different $(\mathrm{p}<0.05)$.

Conclusion: The dyes have been found to reduce the activity of ALP in the skin and serum of the rats. Further studies are still in progress especially as relates to the effect of the dye on the activity of Acid phosphatase which has been implicated in prostate cancer. The decrease in the activity of ALP may not be unrelated to the presence of some highly toxic metals such as $\mathrm{As}, \mathrm{Pb}, \mathrm{Cr}, \mathrm{Co}$ and $\mathrm{Zn}$ in the studied mineral dye. Further work is presently going on in our laboratory with respect to isolation, purification and characterization of organic compounds in the mineral dye.

\section{REFERENCES}

Adetuji, A. O., Popoola, A. V. and Lajide. L. (2003). Isolation and $\mathrm{A}$ colouring potentials of leaf extract of Teak plant (Tectone Grandis). J. Chem. Soc. Nigeria 28 (1), 34-39.

Akanji, M.A., Olagoke, O.A. and Oloyede, O. B. (1993). Effect of chronic consumption of metabisulphite on the integrity of rat liver cellular system. Toxicol. 81, 173 -179 .

Chase, M. (1998). Study shows hair dyes pose scant cancer risk, Wall Street Journal U.S.A.

Coldiz, G.A. (1994): Hair dyes and cancer risk J. Natl. Cancer Inst. 86, 164-165.

De Zwart, D. and Sluoff, W. (1987). Toxicity of Mixtures of heavy metals and petrochemicals to Xenopus laevis. Bull. Environ. Contam. Toxicol. 38, 345-351.
Marcus, M. B. (1997). Lead in hair dyes. US News Online. US News World Report Inc.

Oncolink Team (1999). study sees no link between hair dyes and lymphomas. The Trustees of the University of Pennsylvania, U. S. A.

Patlak, M. (1993). Hair dye dilemmas, US Food and Drug Administration, U.S.A.

Potts, P. J. (1993). Energy Dispersive X-ray spectrometry. A handbook of Silicates Rock Analysis, Blackie, Glasgow, Pp 286-325

Potts, P.J, Webb, P.C. and Waston, J.S. (1984). Energy Dispersive X-Ray Fluorescence Analysis of Silicate Rock for Major and Trace Element. X-Ray Spectrum 13, 2-15.

Umezewa, H. and Hooper, I. R. (1982). Aminoglycoside antibiotics. Spanger Verky, Berlin, Hodelberg New York.

Wayne, P. A. (1994). Natural dyes. Journal of the American Botanical Council 32, 30.

Wright, P. J. and Plummer, D. T. (1974). The use of urinary enzymes measurement to detect renal damage caused by nephrotoxic compounds. Biochem. Phermacol. 23, 65-73 